\title{
Jadwal Imunisasi Anak Usia 0 - 18 tahun Rekomendasi Ikatan Dokter Anak Indonesia 2017
}

Hartono Gunardi, Cissy B. Kartasasmita, Sri Rezeki S. Hadinegoro, Hindra Irawan Satari, Soedjatmiko, Hanifah Oswari, Hardiono D. Pusponegoro, Jose R. Batubara, Arwin AP. Akib, Badriul Hegar, Piprim B. Yanuarso, Toto Wisnu Hendrarto Satuan Tugas Imunisasi IDAI

\begin{abstract}
Abstrak
Ikatan Dokter Anak Indonesia melalui Satuan Tugas Imunisasi mengeluarkan rekomendasi Imunisasi IDAI tahun 2017 untuk menggantikan jadwal imunisasi sebelumnya. Jadwal imunisasi 2017 ini bertujuan menyeragamkan jadwal imunisasi rekomendasi IDAI dengan jadwal imunisasi Kementerian Kesehatan RI khususnya untuk imunisasi rutin. Jadwal imunisasi 2017 juga dibuat berdasarkan ketersediaan kombinasi vaksin DTP dengan hepatitis B seperti DTPw-HB-Hib, DTPa-HB-Hib-IPV, dan dalam situasi keterbatasan atau kelangkaan vaksin tertentu seperti vaksin DTPa atau DTPw tanpa kombinasi dengan vaksin lainnya. Hal baru yang terdapat pada jadwal 2017 antara lain: vaksin hepatitis B monovalen tidak perlu diberikan pada usia 1 bulan apabila anak akan mendapat vaksin DTP-Hib kombinasi dengan hepatitis B; bayi paling sedikit harus mendapat satu dosis vaksin IPV (inactivated polio vaccine) bersamaan (simultan) dengan OPV-3 saat pemberian DTP-3; vaksin DTPw direkomendasikan untuk diberikan pada usia 2,3 dan 4 bulan. Hal baru yang lain adalah untuk vaksin influenza dapat diberikan vaksin inaktif trivalen atau quadrivalen, vaksin MMR dapat diberikan pada usia 12 bulan apabila anak belum mendapat vaksin campak pada usia 9 bulan. Vaksin HPV apabila diberikan pada remaja usia 10-13 tahun, pemberian cukup 2 dosis dengan interval 6-12 bulan; respons antibodi setara dengan 3 dosis. Vaksin Japanese Encephalitis direkomendasikan untuk diberikan mulai usia 12 bulan pada daerah endemis atau pada turis yang akan bepergian ke daerah endemis. Vaksin dengue direkomendasikan untuk diberikan pada anak usia 9-16 tahun dengan jadwal 0, 6, dan 12 bulan. Dengan pemberian imunisasi sesuai rekomendasi, diharapkan anak-anak Indonesia terlindungi dari penyakit infeksi yang dapat dicegah dengan imunisasi. Sari Pediatri 2017;18(5):417-22
\end{abstract}

Kata kunci: imunisasi, dosis, vaksin

\section{Immunization Schedule for Children Aged 0 - 18 Years Old Indonesian Pediatrics Society Recommendation 2017}

Hartono Gunardi, Cissy B. Kartasasmita, Sri Rezeki S. Hadinegoro, Hindra Irawan Satari, Soedjatmiko, Hanifah Oswari, Hardiono D. Pusponegoro, Jose R. Batubara, Arwin AP. Akib, Badriul Hegar, Piprim B. Yanuarso, Toto Wisnu Hendrarto

\begin{abstract}
Indonesia Pediatric Society (IPS) through Immunization Task Force released 2017 IPS Immunization Schedule Recommendation to replace the previous recommendation. The objective of the 2017 recommendation is to combine the previous IPS recommendation and Ministry of Health recommendation. It was made based on the availability of DTP-based combination vaccines (such as DTwP-HB$\mathrm{Hib}$ or DTaP-HB-Hib-IPV) and the scarcity of certain vaccines, such as single DTaP or DTwP vaccine. In the new recommendation, monovalent hepatitis $B$ vaccine need not to be given in the first month of age if the infant will be given combination vaccine containing hepatitis B and DTP; infants should have at least one dose IPV (inactivated polio vaccine) simultaneously with bOPV-3 and DTP-3; DTwP is recommended to be administered at age of 2, 3 and 4 months. Influenza immunization could be given in the form of either trivalent or quadrivalent inactive influenza vaccine. MMR vaccine can be administered at age of 12 months if measles vaccine has not been given in age 9 months. Two doses of HPV vaccine is sufficient for female adolescents age 10-13 years; antibody respons after two doses is not inferior to the three dose regiment. Japanese Encephalitis vaccine is recommended to be given to infants aged 12 months who live in endemic area or for tourist traveling to endemic area. Dengue vaccine is recommended to children age 9-16 years with 0, 6 dan 12 month schedule. Timely immunization according to recommendation will protect Indonesian children from vaccine-preventable diseases. Sari Pediatri 2017;18(5):417-22
\end{abstract}

Keyword: immunization, doses, vaccine

Alamat korespondensi: DR. Dr. Hartono Gunardi, SpA(K). Departemen Ilmu Kesehatan Anak FKUI/RS Cipto Mangunkusumo. Jl. Salemba 6. Jakarta 10430. Email: hartono@ikafkui.net 
$\mathrm{P}$ ada awal tahun 2017, Ikatan Dokter Anak Indonesia melalui Satuan Tugas Imunisasi mengeluarkan rekomendasi Imunisasi IDAI tahun 2017 untuk menggantikan jadwal imunisasi sebelumnya. Jadwal imunisasi 2017 ini dibuat dengan tujuan, pertama menyeragamkan jadwal imunisasi rekomendasi IDAI dengan jadwal imunisasi Kementerian Kesehatan RI khususnya untuk imunisasi rutin, sehingga mempermudah tenaga kesehatan dalam melaksanakan imunisasi. Kedua, jadwal imunisasi 2017 ini juga dibuat berdasarkan ketersediaan kombinasi vaksin DTP dengan hepatitis B seperti DTPw-HBHib, DTPa-HB-Hib-IPV, dan ketiga dalam situasi keterbatasan atau kelangkaan vaksin tertentu seperti vaksin DTPa atau DTPw tanpa kombinasi dengan vaksin lainnya.

Seperti jadwal imunisasi yang lalu, jadwal 2017 juga mencantumkan warna berbeda untuk imunisasi yang diberikan.

- Kolom hijau menandakan imunisasi optimal, yaitu imunisasi diberikan sesuai usia yang dianjurkan.

- Kolom kuning menandakan imunisasi kejar (catchup immunization), yaitu imunisasi yang diberikan di luar waktu yang direkomendasikan.

- Kolom biru menandakan imunisasi penguat atau booster.

- Kolom warna merah muda menandakan imunisasi yang direkomendasikan untuk daerah endemis.

Untuk menerapkan rekomendasi imunisasi IDAI, catatan kaki perlu dibaca karena memuat keterangan yang penting dalam melaksanakan imunisasi. Berikut adalah beberapa catatan penting yang berhubungan dengan pelaksanaan imunisasi rekomendasi IDAI 2017.

\section{Hal baru yang terdapat pada jadwal 2017}

\section{Vaksin hepatitis $B(\mathbf{H B})$}

Vaksin HB monovalen pada usia 1 bulan tidak perlu diberikan apabila anak akan mendapat vaksin DTP-Hib kombinasi dengan HB.

\section{Rasional}

Pada saat ini mayoritas vaksin kombinasi berbahan dasar DTP-Hib yang beredar di Indonesia juga berisi komponen $\mathrm{HB}$ sehingga pada imunisasi dasar dengan vaksin DTPw-Hib-HB atau DTPaHib-HB-IPV akan memberikan 3 dosis vaksin HB di luar vaksin $\mathrm{HB}$ saat lahir. Hal tersebut dapat dilakukan berdasarkan hasil seroproteksi terhadap $\mathrm{HB}$ setelah 3 dosis vaksin pentavalen DTPw-Hib$\mathrm{HB}$ adalah 99,3\%, ${ }^{1}$ dan setelah 3 dosis hexavalen DTPa-Hib-HB-IPV adalah $98,4 \%{ }^{2}$ pada bayi yang telah mendapat vaksin $\mathrm{HB}$ saat lahir.

\section{Vaksin polio}

Bayi paling sedikit harus mendapat satu dosis vaksin IPV (inactivated polio vaccine) bersamaan (simultan) dengan OPV-3 saat pemberian DTP-3.

Rasional

Dalam masa transisi program eradikasi polio, Indonesia telah melakukan switching dari vaksin polio oral trivalen (tOPV) ke vaksin polio oral bivalen (bOPV) yang hanya mengandung virus polio 1 dan 3 pada bulan April 2016. ${ }^{3}$ Galur virus polio tipe 2 dikeluarkan dari OPV karena virus polio tipe 2 liar ini tidak ditemukan lagi sejak tahun 1999. ${ }^{4}$ Alasan terpenting menggantikan OPV karena menimbulkan 250 - 500 kasus vaccine associated paralysis poliomyelitis (VAPP) setiap tahunnya. ${ }^{5}$ Selain itu kejadian luar biasa polio sebagian besar (87\%-97\%) berhubungan dengan vaccine derived polio virus tipe 2 (VDPV2). ${ }^{6}$

Bayi yang hanya mendapat vaksin bOPV tidak mempunyai kekebalan terhadap virus polio 2 sehingga rentan terinfeksi virus polio 2 yang mungkin terjadi karena importasi dari komunitas yang masih menggunakan tOPV. Bayi tersebut perlu mendapatkan IPV yang mengandung 3 virus polio inaktif. Strategic Advisory Group of Experts (SAGE) merekomendasikan paling sedikit satu dosis IPV tambahan dalam jadwal imunisasi rutin di negara yang hanya menggunakan OPV. ${ }^{5}$ Vaksin IPV menimbulkan serokonversi $69 \%$ terhadap virus polio 2 pada anak yang sebelumnya mendapat bOPV dan satu dosis IPV. ${ }^{7}$ Kekebalan mukosa terhadap virus polio 1 dan 3 juga meningkat dengan pemberian IPV pada anak yang telah mendapat bOPV sehingga mempercepat eradikasi polio. ${ }^{8}$ Saat terbaik pemberian IPV adalah bersamaan dengan pemberian DTP3 dan bOPV3 yaitu pada keadaan antibodi maternal polio terendah sehingga memberikan imunogenisitas paling optimal. ${ }^{8}$ 


\section{Vaksin difteri, tetanus, dan pertusis (DTP)} Vaksin DTP dosis pertama dapat berupa vaksin DTPw atau DTPa atau kombinasi dengan vaksin lain, diberikan paling cepat pada bayi usia 6 minggu. Apabila diberikan vaksin DTPw maka interval mengikuti rekomendasi vaksin tersebut yaitu usia 2, 3, dan 4 bulan. Apabila diberikan vaksin DTPa, interval mengikuti rekomendasi vaksin tersebut yaitu usia 2, 4, dan 6 bulan. Vaksin DTPw dan DTPa dapat saling dipertukarkan (interchangibility) pada keadaan mendesak. Untuk anak usia lebih dari 7 tahun diberikan vaksin $\mathrm{Td}$ atau Tdap. Untuk DTP6 dapat diberikan vaksin Td/Tdap pada usia 10-12 tahun. ${ }^{9}$ Vaksin Td booster diberikan setiap 10 tahun. ${ }^{10}$

Rasional

Vaksin DTPw-HB-Hib pada anak Indonesia memberikan seroproteksi yang baik pada pemberian usia 2, 3, dan 4 bulan. ${ }^{1}$ Jadwal imunisasi dengan menggunakan DTPa pada usia 2, 3, dan 4 bulan juga digunakan di negara maju seperti Austria, Jerman dan Perancis. ${ }^{11}$ Vaksin DTP tidak dianjurkan untuk anak $>7$ tahun, penggantinya diberikan $\mathrm{Td} /$ Tdap. ${ }^{12}$ Vaksin Tdap dianjurkan untuk diberikan satu kali terbaik pada usia 10-12 tahun. Imunisasi booster diberikan $\mathrm{Td}$ setiap 10 tahun. Tdap direkomendasikan untuk diberikan pada remaja hamil dan pada setiap kehamilan remaja. ${ }^{12}$

\section{Vaksin influenza}

Saat ini tersedia vaksin influenza inaktif trivalen dan quadrivalen.

Rasional

Vaksin influenza trivalen (2 serotipe influenza A dan 1 serotipe influenza B) dan quadrivalen (2 serotipe influenza A dan 2 serotipe influenza B) direkomendasikan oleh WHO. ${ }^{13}$

5. Vaksin measles, mumps, rubella (MMR/MR) Vaksin MMR dapat diberikan pada usia 12 bulan, apabila anak belum mendapat vaksin campak pada usia 9 bulan.

Rasional

MMR dapat diberikan pada usia 12 bulan, sesuai anjuran Advisory Committee on Immunization Practices. ${ }^{12}$

\section{Vaksin human papiloma virus (HPV)}

Apabila diberikan pada remaja usia 10-13 tahun, pemberian cukup 2 dosis dengan interval 6-12 bulan; respons antibodi setara dengan 3 dosis.

Rasional

Penelitian vaksin HPV di India mendapatkan bahwa 2 dosis vaksin HPV pada remaja usia 9-13 tahun menghasilkan antibodi yang tidak lebih rendah dibandingkan dengan 3 dosis vaksin HPV. ${ }^{14}$ Pemberian vaksin HPV 2 dosis pada anak usia 10-13 tahun juga telah direkomendasikan oleh WHO. ${ }^{15}$

7. Vaksin Japanese encephalitis (JE)

Vaksin JE diberikan mulai usia 12 bulan pada daerah endemis atau turis yang akan bepergian ke daerah endemis tersebut. Untuk perlindungan jangka panjang dapat diberikan booster 1-2 tahun berikutnya.

\section{Rasional}

Virus JE sudah merupakan masalah pada beberapa daerah endemis di Indonesia, seperti daerah tertentu di propinsi Bali. Vaksin JE direkomendasikan untuk wisatawan yang akan tinggal selama lebih dari 1 bulan di daerah endemi selama masa transmisi virus JE. Vaksin JE dipertimbangkan untuk wisatawan yang akan tinggal kurang dari satu bulan di daerah endemis JE jika memiliki rencana mengunjungi daerah rural, daerah outbreak JE, atau tanpa kepastian mengenai tujuan, aktivitas, atau durasi kunjungan. ${ }^{16} \mathrm{WHO}$ merekomendasikan vaksin JE harus diintegrasikan pada program imunisasi nasional pada daerah JE merupakan prioritas. Meskipun jumlah kasus JE rendah, imunisasi harus dipertimbangkan pada lingkungan yang cocok untuk transmisi virus JE seperti hewan reservoir atau berdekatan dengan daerah yang memiliki transmisi virus JE. ${ }^{17}$

\section{Vaksin dengue}

Vaksin dengue yang disetujui oleh WHO saat ini adalah vaksin hidup tetravalen untuk anak berusia 9 - 16 tahun. Vaksin diberikan 3 kali dengan jadwal 0, 6, dan 12 bulan. Dosis vaksin 0,5 ml setiap pemberian.

Rasional

WHO merekomendasikan pemberian vaksin 
dengue sebagai pencegahan penyakit dengue serotipe $1,2,3$, dan 4 pada usia $9-16$ tahun yang tinggal pada daerah endemis. Batas usia 9 tahun dipilih berdasarkan faktor keamanan. Vaksin dengue telah dilakukan uji klinis pada puluhan ribu partisipan di lima negara Asia dan lima negara Amerika Latin. Vaksin ini menimbulkan imunogenitas lebih tinggi pada anak yang sebelumnya pernah terinfeksi dengue(seropositif). Efikasi vaksin dengue untuk semua serotipe pada 25 bulan pemantauan setelah dosis pertama pada anak di atas 9 tahun adalah 65.6\%. Efikasi vaksin pada anak yang seropositif saat dilakukan vaksinasi $81.9 \%$ dan seronegatif $52.5 \% .^{18}$ Vaksinasi dengue menurunkan rawat inap di rumah sakit $80 \%$ dan mencegah $92,9 \%$ infeksi dengue berat. Mengingat tingginya beban penyakit dengue pada negara-negara endemis, vaksin dengue memberikan dampak kesehatan masyarakat jika diberikan bersama upaya penanggulangan infeksi dengue lainnya (seperti perbaikan tata laksana kasus dan KLB, perbaikan pengendalian vektor, dan peningkatan partisipasi masyarakat). ${ }^{19}$

\section{Rangkuman}

Jadwal imunisasi rekomendasi IDAI 2017 merupakan penyatuan rekomendasi IDAI sebelumnya dengan jadwal imunisasi nasional dan dibuat berdasarkan evidence sahih saat ini. Dengan pemberian imunisasi sesuai rekomendasi, diharapkan anak-anak Indonesia terlindungi dari penyakit infeksi yang dapat dicegah dengan imunisasi.

\section{Daftar pustaka}

1. Rusmil K, Gunardi H, Fadlyana E, Soedjatmiko, Dhamayanti M, Sekartini R, dkk. The immunogenicity, safety, and consistency of an Indonesia combined DTP-HB-Hib vaccine in expanded program on immunization schedule. BMC Pediatrics 2015;15:219.

2. Kosalaraksa P, Thisyakorn U, Benjaponpitak S, Chokephaibulkit $\mathrm{K}$, Santos-Lima E. Immunogenicity and safety study of a new DTaP-IPV-Hep B-PRP-T combined vaccine compared to a licensed DTaP-IPV-Hep B//PRP-T comparator, both concomitantly administered with a 7 -valent pneumococcal conjugate vaccine at 2, 4, and 6 months of age in Thai infants. Int J Infect Dis 2011;15:e249-56.

3. Kementerian Kesehatan RI. Petunjuk teknis penggantian tOPV menjadi bOPV dan introduksi IPV. Jakarta: Kementerian Kesehatan RI; 2015.

4. Center for Disease Control and Prevention. Apparent global interruption of wild poliovirus type 2 transmission. MMWR Morb Mortal Wkly Rep 2001;50:222-4.

5. Sutter RW, Platt L, Mach O, Jafari H, Aylward RB. The new polio eradication end game: rationale and supporting evidence. J Infect Dis 2014;210 Suppl 1:S434-8.

6. Burns CC, Diop OM, Sutter RW, Kew OM. Vaccine-derived polioviruses. J Infect Dis 2014;210 Suppl 1:S283-93.

7. Sutter RW, Bahl S, Deshpande JM, Verma H, Ahmad M, Venugopal P, dkk. Immunogenicity of a new routine vaccination schedule for global poliomyelitis prevention: an openlabel, randomised controlled trial. Lancet 2015;386:2413-21.

8. World Health Organization. Polio vaccines: WHO position paper. Wkly Epidemiol Rec 2014;89:73-92.

9. Hadinegoro SRS, Ismoedijanto, Tumbelaka AR. Difteria, Tetanus, Pertusis. Dalam: Ranuh IGN, Suyitno H, Hadinegoro SRS, Kartasasmita CB, Ismoedijanto, Soedjatmiko, penyunting. Pedoman Imunisasi di Indonesia. Edisi 4. Jakarta: Satgas Imunisasi Ikatan Dokter Anak Indonesia, 2014. h. 271-83.

10. World Health Organization. Diphtheria vaccine: position paper. Wkly Epidemiol Rec 2006;81:24-32.

11. Wirsing von Konig CH, Campins-Marti M, Finn A, Guiso $\mathrm{N}$, Mertsola J, Liese J. Pertussis immunization in the global pertussis initiative European region: recommended strategies and implementation considerations. Pediatr Inf Dis J 2005;24(5 Suppl):S87-92.

12. Centers for Disease Control and Prevention. Recommended Immunization Schedule for Children and Adolescents Aged 18 Years or Younger, United States, 2017. Diakses 28 Januari 2017. Diunduh dari: www.cdc.gov/vaccines/hcplacip-recs/index. html.

13. World Health Organization. Recommended composition of influenza virus vaccines for use in the 2016-2017 northern hemisphere influenza season. Diakses 15 Desember 2016. Diunduh dari: http://www.who.int/influenza/vaccines/virus/ recommendations/201602_recommendation.pdf.

14. Sankaranarayanan R, Prabu PR, Pawlita M, dkk. Immunogenicity and HPV infection after one, two, and three vaccine in girls in India: a multicenter prospective cohort study. Lancet Oncol 2016;17:67-77.

15. World Health Organization. Human papillomavirus vaccines: WHO position paper. Wkly Epidemiol Rec 2014;89:465-91.

16. Pusponegoro H. Japanese Ensefalitis. Dalam: Ranuh IGN, Suyitno H, Hadinegoro SRH, Kartasasmita CB, Ismoedijanto, 
Soedjatmiko, penyunting. Pedoman Imunisasi di Indonesia. Edisi 5. Jakarta: Badan Penerbit Ikatan Dokter Anak Indonesia; 2014. h.363-7.

17. World Health Organization. Japanese Encephalitis vaccines: WHO position paper. Wkly Epidemiol Rec 2015;90:69-88.

18. World Health Organization. Dengue vaccine: WHO position paper. Wkly Epidemiol Rec 2016;30:349-64.

19. Capeding MR, Tran NH, Hadinegoro SR, Ismail HI, Chotpitayasunondh T, dkk. Clinical efficacy and safety of a novel tetravalent dengue vaccine in healthy children in Asia: a phase 3, randomised, observer-masked, placebo-controlled trial. Lancet 2014; 384:1358-65. 


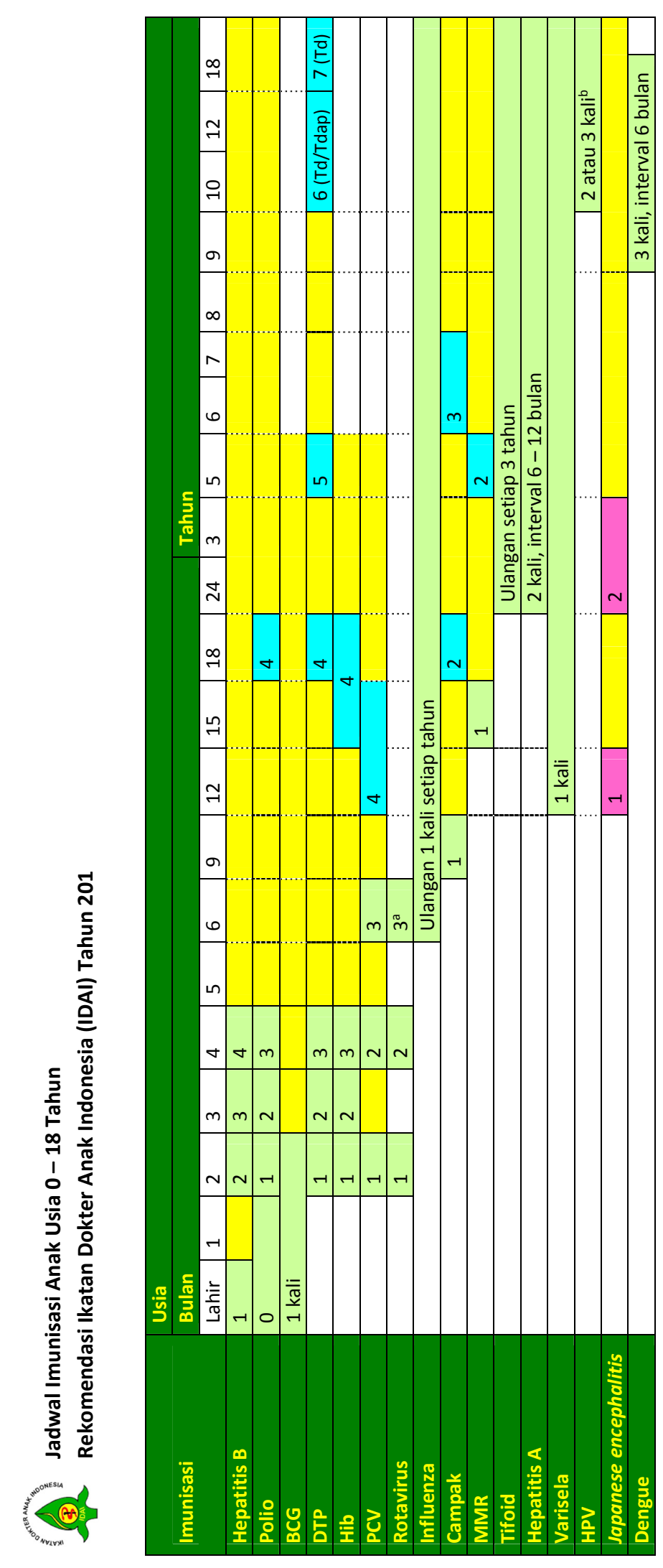

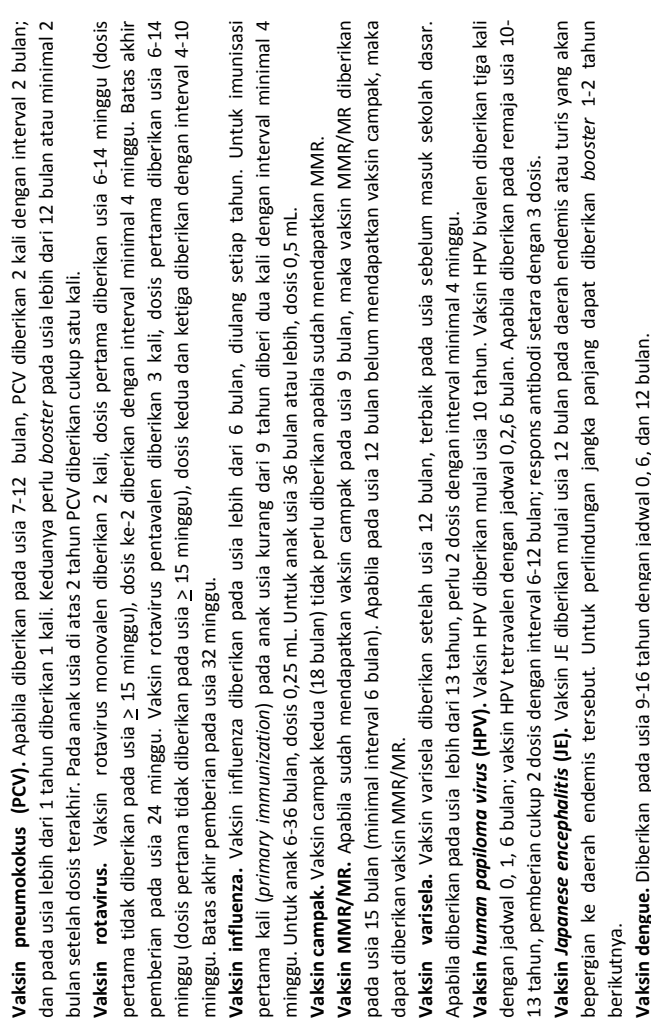

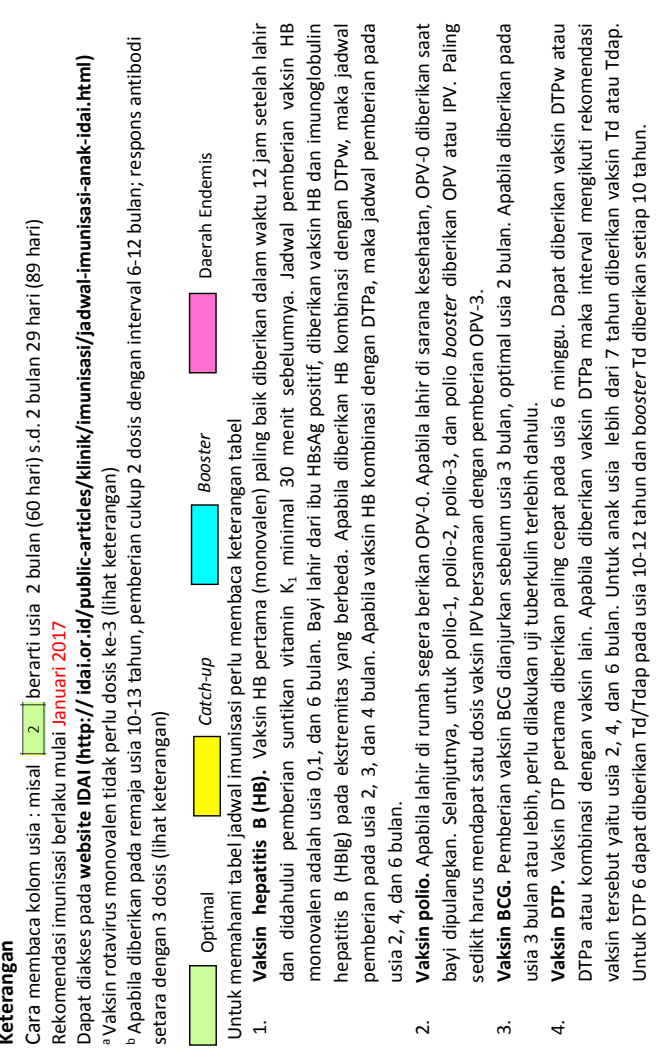

